\title{
Disaster Management of Forest and Peatland Fire Through The Berdikari Gambut Village Program in Pakning River, Bengkalis District
}

\section{Wahyu Purwanto, Rahmad Hidayat, Anugraheni Utami}

PT Pertamina RU II Sungai Pakning, Bengkalis

wahyup.geo09@gmail.com

Article History

accepted 31/08/2020

approved 22/09/2020

published 28/10/2020

\begin{abstract}
Riau is one of the areas that often occurs due to haze disasters due to forest and land fires in Indonesia. One of the causes of fire is difficult to extinguish because most of the burned area is peatland. Several attempts have been made to deal with this forest and land fire disaster, both from the government, community and private sector. In this paper, we will discuss how to overcoming land and forest fire disasters in the Sungai Pakning, Bengkalis Regency through the PT Pertamina RU II Sungai Pakning Kampung Gambut Berdikari CSR program. The research method used descriptive qualitative research. The result is that the Kampung Gambut Berdikari Program is able to overcome the problem of land and forest fires in the Sungai Pakning, as evidenced in 2018 to 2020 in the Sungai Pakning region there has been no forest and land fires again (zero fire).
\end{abstract}

Keywords: Fires, Peatland, CSR

\section{Abstrak}

Riau merupakan salah satu wilayah yang sering terjadi bencana asap akibat kebakaran hutan dan lahan yang ada di Indonesia. Salah satu yang menyebabkan kebakaran sulit dipadamkan karena sebagian besar area terbakar merupakan lahan gambut. Beberapa upaya telah dilakukan untuk menangani bencana kebakaran hutan dan lahan ini, baik dari pemerintah, masyarakat maupun swasta. Dalam makalah ini akan dibahas tentang bagaimana upaya penanganan bencana kebakaran hutan lahan yang ada di Sungai Pakning, Kabupaten Bengkalis melalui program Kampung Gambut Berdikari CSR PT Pertamina RU II Sungai Pakning. Metode penelitian yang digunakan adalah penelitian deskriptif kualitatif. Hasilnya Program Kampung Gambut Berdikari mampu mengatasi masalah kebakaran lahan dan hutan yang ada di Sungai Pakning, terbukti pada tahun 2018 hingga 2020 di wilayah Sungai Pakning sudah tidak terjadi kebakaran hutan dan lahan kembali (zero fire).

Kata kunci: Kebakaran, Gambut, CSR

Social, Humanities, and Education Studies (SHEs): Conference Series https://jurnal.uns.ac.id/shes 


\section{PENDAHULUAN}

Bencana kebakaran hutan dan lahan yang ada di Indonesia merupakan salah satu bencana rutin yang terjadi dalam beberapa tahun terakhir. Imbas bencana ini menyebabkan terjadinya kabut asap yang melanda tak hanya di dalam negeri tetapi hingga negara - negara tetangga seperti Singapura dan Malaysia. Hal ini menjadikannya tak hanya bencana lokal tetapi sebagai bencana nasional. Salah satu provinsi yang terdampak paling parah ialah Riau. Kebakaran lahan dan hutan yang ada di Riau ini terjadi akibat beberapa hal baik secara disengaja maupun tidak disengaja.

Menurut Wahana Lingkungan Hidup Indonesia atau Walhi, kebakaran hutan dan lahan di Riau merupakan salah satu bencana tahunan yang disebabkan oleh perilaku manusia. Fakta lapangan menunjukkan bahwa ada faktor kesengajaan membakar hutan dan lahan. Tujuan pembakaran tersebut adalah untuk melakukan pembersihan lahan dalam rangka persiapan pembangunan perkebunan.

Kebakaran lahan dan hutan ini menimbulkan kerugian baik materiil hingga korban jiwa. Kebakaran juga menyebabka terjadinya degradasi lahan gambut yang menimbulkan besarnya emisi karbon yang lepas di udara dan juga hilangnya biodiversitas di sekitarnya. (Johansen, 2015). Bahkan bencana kebakaran hutan dan lahan pada tahun 2016 ini juga mengakibatkan kerugian besar kurang lebih US\$16 milyar di sektor lingkungan hidup, ekonomi, wisata, maupun pendidikan (CIFOR, 2018).

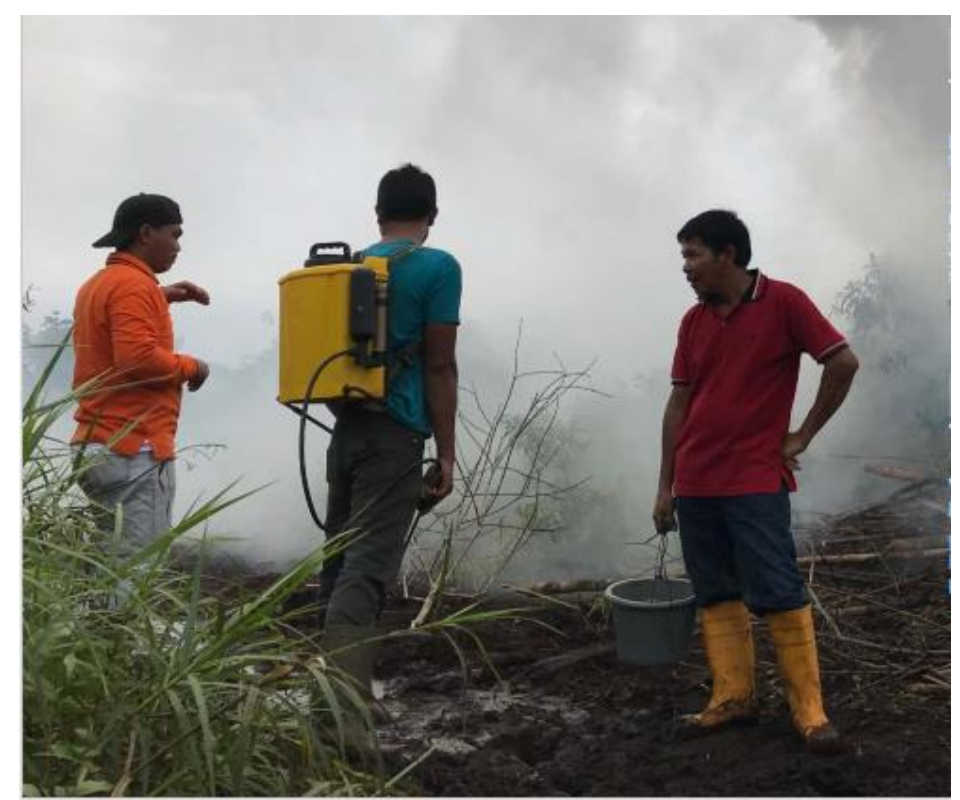

Gambar 1. Kebakaran Lahan di Sungai Pakning

Di Sungai Pakning, Kabupaten Bengkalis, ketika terjadi bencana kebakaran lahan dan hutan menimbulkan banyak kerugian antara lain 86 ha lahan produktif yang terbakar, terganggunya aktifitas masyarakat, hingga menimbulkan korban jiwa akibat ISPA. Oleh karena itu PT Pertamina RU II Sungai Paning, sebagai salah satu perusahaan yang berada di wilayah Sungai Pakning, Bengkalis, Provinsi Riau ikut andil dalam upaya penanganan bencana kebakaran hutan dan lahan melalui program CSR (Coorporate Social Responsibility) dengan Program Kampung Gambut Berdikari dengan mitra binaan Petani, MPA, sekolah - sekolah dan beberapa masyarakat lainnya.

Kesulitan utama dalam upaya mitigasi bencana asap dari kebakaran lahan dan hutan ialah berbenturnya antara kebutuhan ekonomi masyarakat dengan upaya konservasi yang dilaksanakan. Sebagian besar MPA merupakan pengangguran tapi disisi lain mereka menjadi sukarelawan untuk patroli dan pemadaman sehingga sering kali mereka terpecah fokusnya antara mencari nafkah dengan pemadaman. Selain itu sebagian besar masyarakat juga belum memiliki pemahaman terhadap gambut, sehingga masih banyak yang belum paham mengenai 
pengelolaan gambut yang baik dan benar. Masih banyak juga yang melakukan pembakaran untuk membuka lahan pertanian sehingga sangat riskan terjadinya kebakaran.

\section{METODE}

Penelitian ini dilakukan menggunakan metode kualitatif yang merupakan prosedur penelitian untuk menghasilkan data deskriptif dari obyek penelitian yang diamati. Metode ini melihat pengalaman individu/organisasi secara utuh, sehingga tidak membatasi pernyataan individu/organisasi ke dalam hipotesis tertentu. Pengumpulan data dilakukan melalui observasi partisipan dan Focus Group Discussion (FGD). Informan penelitian dipilih berdasarkan purposive sampling dengan maksud agar informan yang dipilih sudah mengetahui permasalahan secara mendalam sehingga dapat memberikan informasi yang utuh.

\section{HASIL DAN PEMBAHASAN}

Program Kampung Gambut Berdikari PT Pertamina RU II Sungai Pakning terdiri dari beberapa program yang berkaitan dengan upaya mitigasi bencana kebakaran hutan dan lahan yang ada di Sungai Pakning, Program-program tersebut antara lain :

a. Konservasi Lahan Gambut

Dalam upaya pengelolaan lahan gambut yang baik, program pertama yang dilakukan oleh PT Pertamina RU II Sungai Pakning ialah konservasi lahan gambut. Konservasi lahan gambut ini dilakukan dengan cara penanaman tanaman khas gambut pada lahan bekas terbakar dan pengelolaan lahan yang selamat dari kebakaran dengan membuat menjadi Arboretum Gambut yang berisikan tanamantanaman khas gambut.

Pembuatan Arboretum Gambut ini bekerjasama dengan Masyarakat Peduli Api (MPA) Sungai Pakning beserta Kelmpok Tani Tunas Makmur. Lokasi Arboretum Gambut berada di Kampung Jawa, Sungai Pakning Kabupaten Bengkalis. Pada lahan yang terselamatkan dari kebakaran tersebut dilakukan penanaman tanaman-tanaman khas gambut dan konservasi tanaman-tanaman langka seperti Nepenthes sumatrana yang berstatus CR (critically endangered).

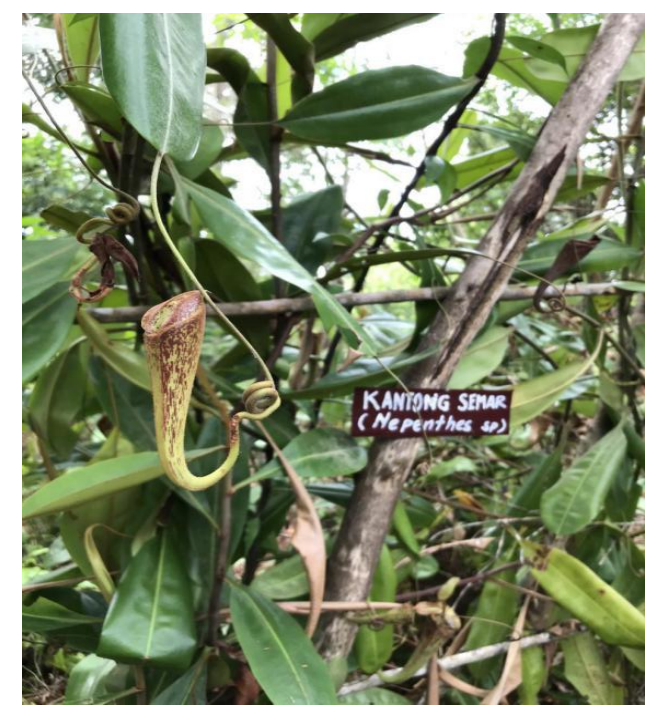

Gambar 2. Nepenthes sumatrana (critically endangered) di Arboretum Gambut

Di Arboretum Gambut ini kelompok bersama PT Pertamina RU II Sungai Pakning mengidentifikasi tanaman khas gambut yang terselamatkan dari kebakaran lahan dan hutan, serta berupaya membudidayakan tanaman khas gambut sehingga tidak terancam akan kepunahan. Arboretum gambut juga menjadi sarana pembelajaran bagi sekolah maupun universitas yang ada di sekitarnya sebagai laboratorium pembelajaran lapangan. Sehingga dengan adanya pembelajaran di arboretum akan memberikan pengetahuan tentang gambut yang 
baik bagi para siswa, dan diharapkan dimasa depan siswa ini akan ikut menjaga lingkungan gambut dari kebakaran lahan dan hutan.

Secara ekonomi arboretum gambut juga memberikan pemasukan tersendiri bagi kelompok pengelola dari hasil penjualan tiket, makanan, maupun tanamantanaman hasil budidaya yang bisa dibawa pulang oleh pengunjung. Berikut beberapa foto Arboretum Gambut yang ada di Sungai Pakning :

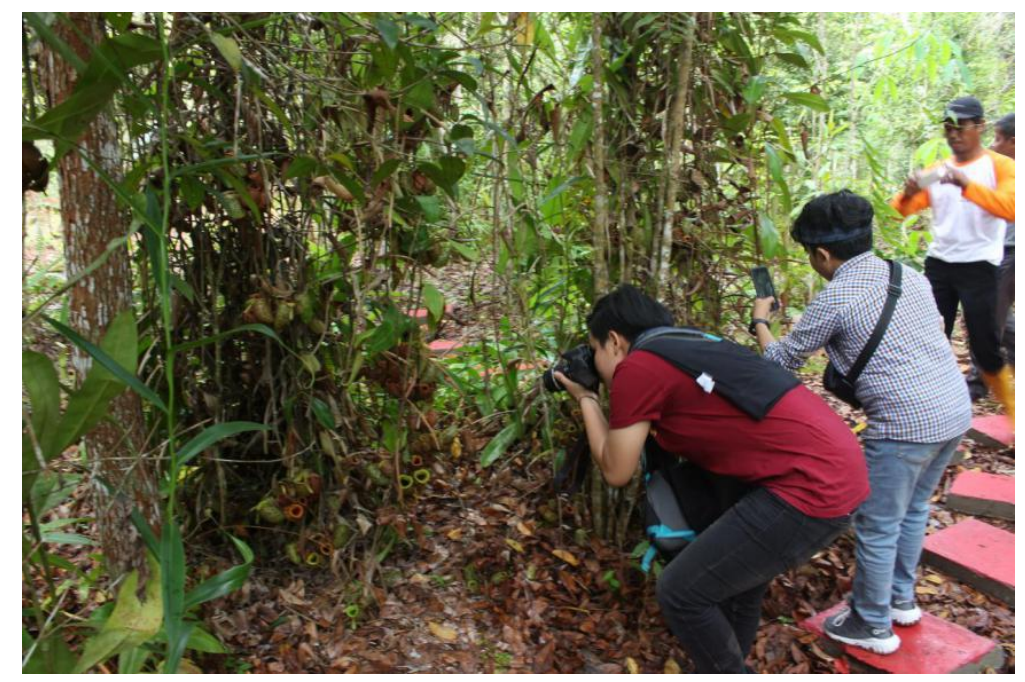

Gambar 3. Ekowisata Arboretum Gambut

b. Pemberdayaan di Lahan Gambut

Pemberdayaan yang dilakukan oleh Pertamina RU II Sungai Pakning salah satunya ialah dengan penanaman lahan bekas terbakar yang ada di Sungai Pakning. Kegiatan ini dilakukan kelompok Tani Tunas Makmur dan Kelompok Masyarakat Peduli Api Kelurahan Sungai Pakning. Penanaman pada lahan bekas terbakar ini bertujuan mengubah semak yang rawan terbakar menjadi lahan pertanian yang produktif dan menurunkan tingkat risiko kebakaran lahan.

Saat ini lahan bekas terbakar yang dilakukan penanaman bersama ini seluas 25 ha, yang terdiri dari tanaman budidaya semusim seperti nanas dan serai wangi serta tanaman keras seperti durian, matoa, jengkol, dan sirsak. Dipilihnya jenisjenis tanaman tersebut karena selain bernilai ekonomis juga tidak perlu dilakukan pengolahan lahan lanjutan seperti pembakaran lahan gambut untuk penanaman. Gambar lokasi penanaman pada lahan bekas terbakar dapat dilihat pada gambar 4.

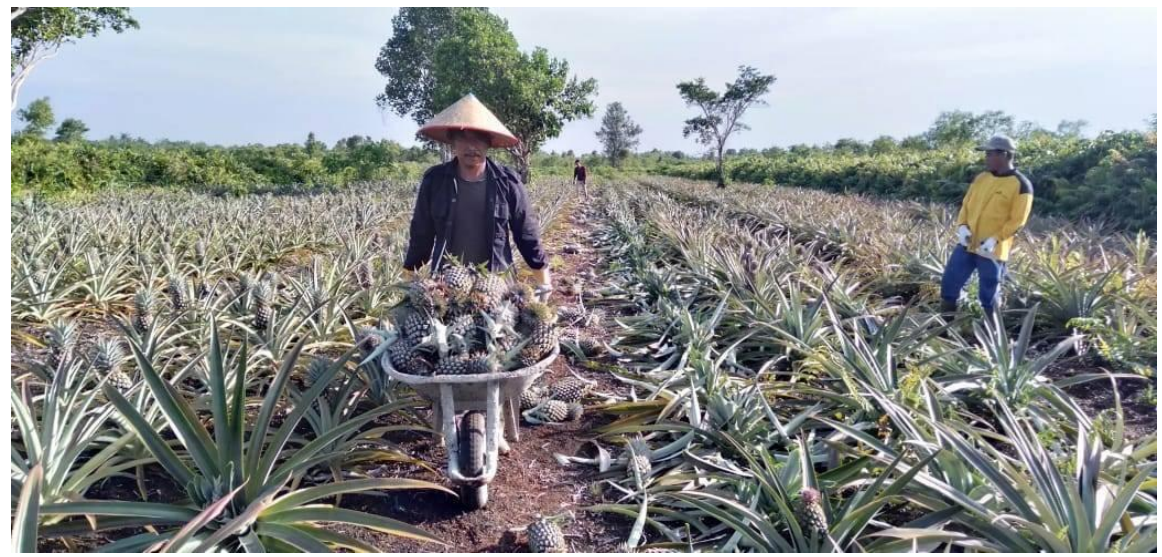

Gambar 4. Lokasi penanaman lahan bekas terbakar di Sungai Pakning 
Selain itu pemberdayaan di lahan gambut juga dilakukan dengan memberdayakan Masyarakat Peduli Api (MPA) dengan kegiatan-kegiatan perekenomian sesuai dengan potensi di masing-masing desa. Kegiatan ini bertujuan untuk memberikan penghasilan tambahan bagi anggota MPA di masingmasing desa, karena MPA merupakan kegiatan sukarela masyarakat yang menjadi garda terdepan dalam penanganan kebakaran hutan dan lahan.

Hal tersebut penting dilakukan karena sebagian besar MPA belum memiliki pekerjaan yang tetap, sehingga masih sulit juga dalam pemenuhan kebutuhan. Dengan adanya program ini antusias masyarakat untuk menjadi MPA semakin meningkat, sehingga keberadaan personil MPA akan selalu ada. Beberapa program kewirausahaan yang diberikan kepada MPA antara lain budidaya ikan lele, budidaya lebah madu, budidaya jamur tiram, pemberdayaan safetyman dan fireman, serta usaha konveksi. Tak hanya itu MPA juga dibekali secara rutin pelatihan-pelatihan pemadaman serta didaftarkan sertifikasi fireman level D di Badan Nasional Sertifikasi Profesi (BNSP), sehingga MPA mampu memadamkan api secara professional.

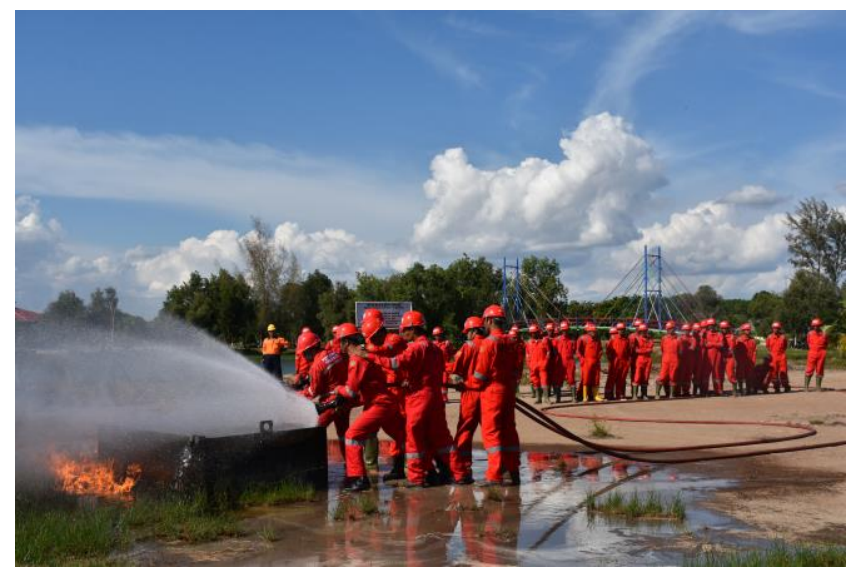

Gambar 5. Program Sertifikasi Safetyman dan Fireman untuk MPA

Terakhir program budidaya madu juga tak hanya bagi MPA tetapi juga dilakukan bagi pemburu madu hutan. Hal yang membuat program ini juga memberikan andil terhadap penangan kebakaran hutan dan lahan karena beberapa tahun belakang isu yang berkembang di masyarakat penyebab kebakaran hutan dan lahan salah satunya akibat aktivitas para memburu madu lebah hutan liar, karena pada saat proses pemburuan madu di hutan, mereka melakukan pengasapan ke sarang lebah dan tanpa disadari beberapa bahan bakar yang mereka gunakan memicu terjadinya kebakaran. Melalui program ini Pertamina melakukan adukasi kepada pemburu lebah untuk melakukan pengasapan yang aman selain itu memberikan program budidaya lebah madu di sekitar tempat tinggal pemburu madu, sehingga juga mengurangi intensitas aktivitas pemburu madu di dalam hutan yang riskan menjadi penyebab terjadinya kebakaran hutan dan lahan. 


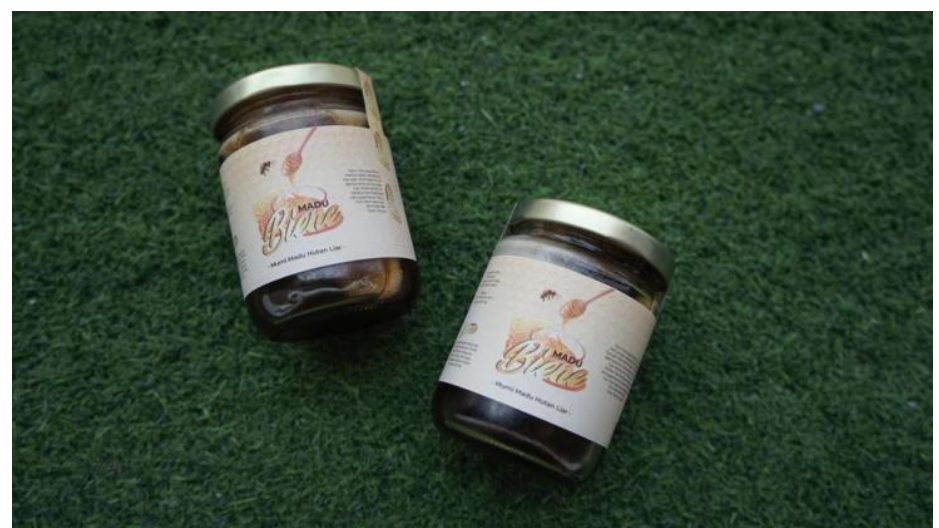

Gambar 6. Madu Produk Binaan PT Pertamina RU II Sungai Pakning

c. Pendidikan Gambut

Dalam penanganan kebakaran hutan dan lahan, juga perlu memikirkan pendidikan kebencanaan, terutama pada anak - anak sejak usia dini. Pentingnya pendidikan kebencanaan ini karena selama ini banyak masyarakat yang belum paham mengenai lahan gambut. Dengan adanya program pendidikan gambut ini diharapkan akan mampu mengubah mainset masyarakat local tentang lahan gambut yang ada disekitar mereka. Saat ini banyak beranggapan bahwa lahan gambut merupakan tanah yang mudah terbakar, sulit dikelola, dan sebagainya, sehingga dengan adanya pendidikan gambut ini masyarakat akan semakin mengenal lahan gambut dari segi konservasi, pengolahan hingga potensi bencananya.

Program pendidikan kebencanaan di lahan gambut ini dikemas kedalam elearning dan buku yang menarik bagi anak-anak, sehingga belajara mengenai gambut akan terkesan menyenangkan. Pembelajaran gambut ini dapat diakses di sekolahcintagambut.com dan dapat pula didownload buku-buku mengenai gambut. Selain itu juga telah dilakukan penyususnan kurikulum sekolah cinta gambut yang diterapkan di sekolah binaan PT Pertamina RU II Sungai Pakning. Hasilnya siswasiswa pada sekolah binaan tersebut telah paham mengenai lahan gambut dan mampu mengedukasi juga masyarakat disekitar tempat tinggal mereka termasuk orang tua mereka sendiri. Gambar buku dan game terkait pendidikan gambut dapat dilihat pada gambar 7 dan gambar 8 .

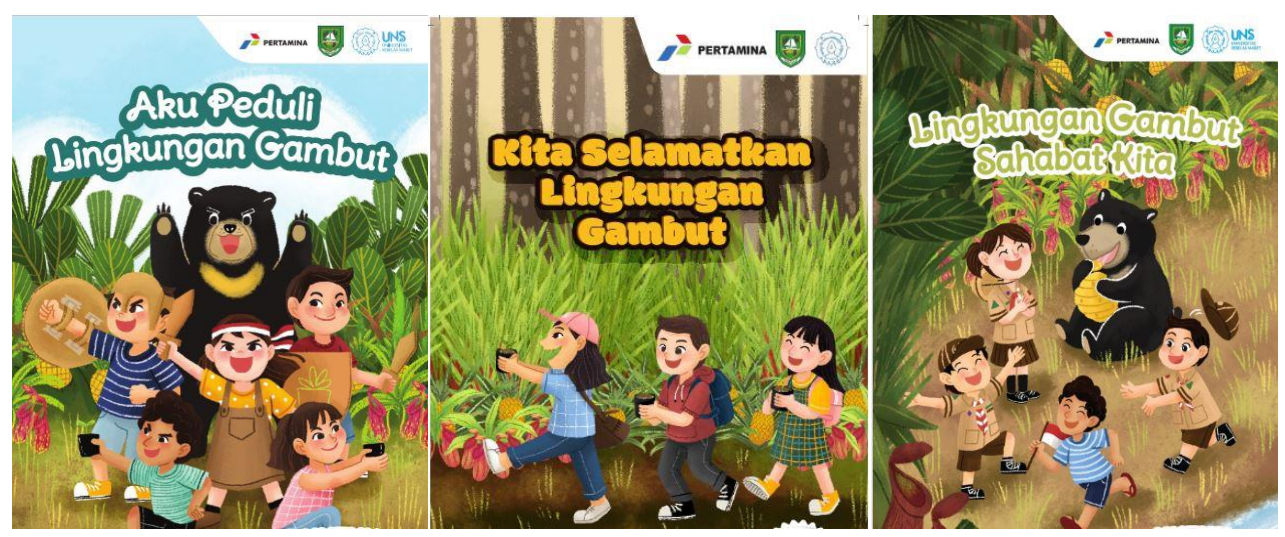

Gambar 7. Buku Pendidikan Gambut 


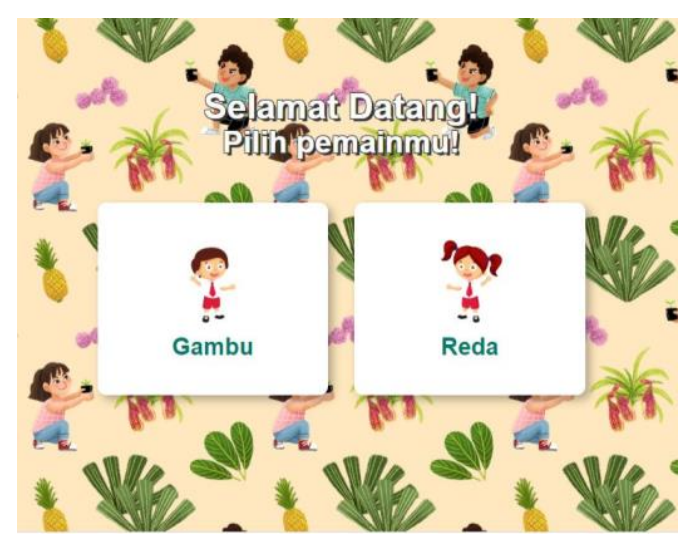

Gambar 8. Game Edukasi Gambut

Selain itu di usia remaja Pertamina RU II Sungai Pakning juga membuat Program Pertamina EcoCamp, di kegiatan ini siswa SMA maupun mahasiswa diberikan materi mengenai lingkungan khususnya tentang lingkungan gambut. Tujuannya ialah memberikan edukasi terkait gambut kepada anak - anak milenial sehingga menciptakan generasi milenial yang cinta lingkungan dan sadar akan gambut.

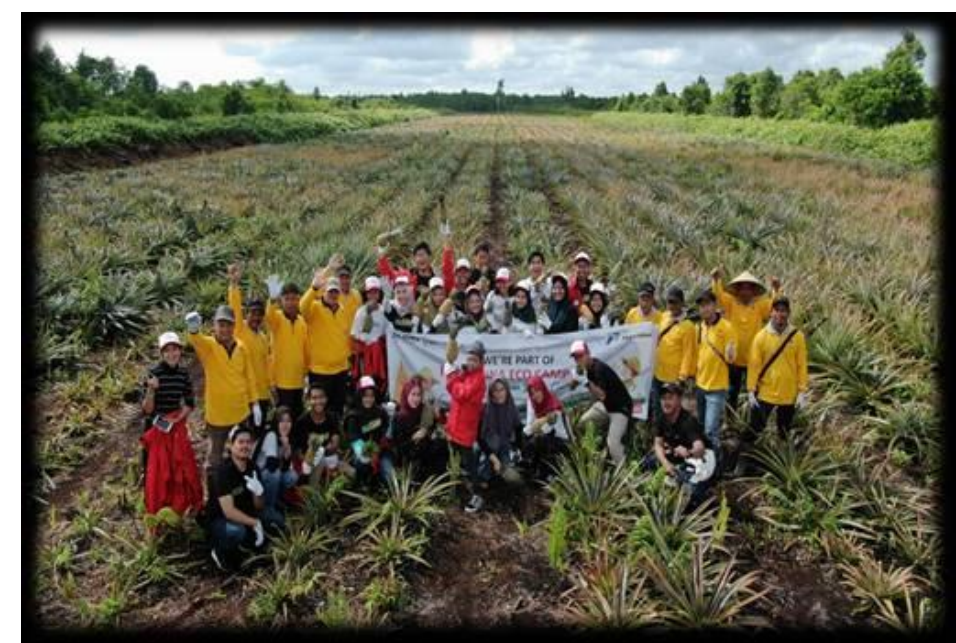

Gambar 9. Kegiatan Pertamina Eco Camp 2019

d. Sistem Komunikasi Penanganan Karhutlah

Dalam proses penanganan kebakaran hutan dan lahan, Pertamina RU II Sungai Pakning membentuk system informasi bersama Masyarakat umum, FORKOMPA (Forum Masyarakat Peduli Api) serta Stakeholder-stakeholder terkait, sehingga proses pemadaman bisa dilakukan sedini mungking apabila terjadi kebakaran. Selain itu juga dilakukan pembagian peran antar stakeholder terkait sesuai dengan instansinya. Proses alur komunikasi deteksi dini kebakaran lahan dan hutan yang telah diterapkan di Sungai Pakning dapat dilihat pada gambar 10. 


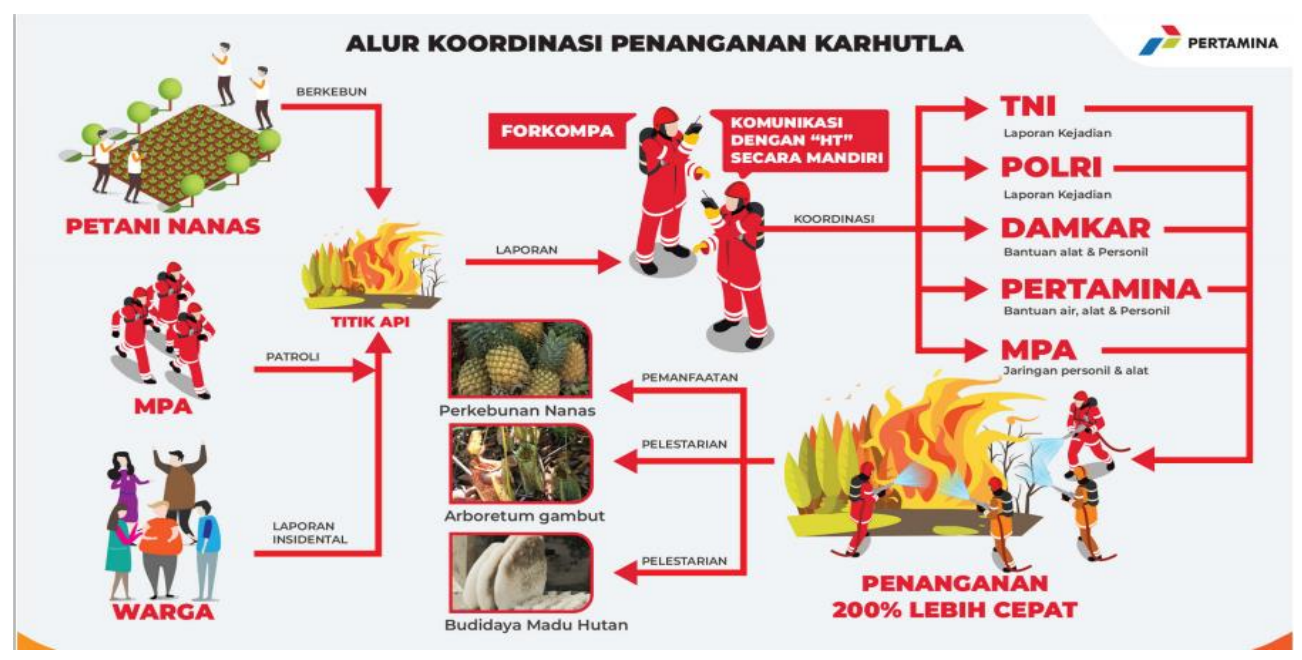

Gambar 10. Alur Koordinasi Penanganan Karhutla di Sungai Pakning

\section{SIMPULAN}

Program Kampung Gambut Berdikari memberikan penanganan bencana kebakaran hutan dan lahan melalui beberapa cara yaitu konservasi lahan gambut pada lahan bekas terbakar maupun lahan yang selamat dari kebakaran, membuat pemberdayaan di lahan gambut dengan menggandeng kelompok tani dan MPA, sehingga masyarakat mendapatkan manfaat ekonomi dari kegiatan yang ada di lahan gambut sehingga meraka akan semakin menjaganya, dan yang terakhir melalui kegiatan pendidikan kebencanaan di lahan gambut, yaitu dengan mengedukasi anak anak tentang lahan gambut sejak dini, serta untuk level usia remaja dibekali pengetahuan tentang gambut, sehingga mereka mampu mengedukasi lingkungan sekitarnya dan mempersiapkan generasi milenial yang paham akan lahan gambut sehingga akan mampu mencegah bencana kebakaran hutan dan lahan. Dengan adanya program Kampung Gambut Berdikari CSR PT Pertamina RU II Sungai Pakning, saat ini di wilayah Sungai Pakning telah memperoleh predika zero fire dari BPBD Kabupaten Bengkalis (2019).

\section{DAFTAR PUSTAKA}

Afandy, dkk. (2019). Monitoring dan Evaluasi Program Arboretum Gambut Marsawa 2019. Bogor : PKSPL IPB.

Irma, Widarti, dkk. (2017). Pengelolaan Ekosistem Lahan Gambut Dengan Mempertahankan Biodiversitas Vegetasi di Hilir DAS Kampar Riau Sumatera. Prosiding Pengelolaan Sumberdaya Wilayah Berkelanjutan. ISBN : 978-602-361-0723.

Johansen, Marte Dalen. (2015) Restoration of peatland by natural revegation from indigenous soils along. Thesis. Faculty of Environmental Science and Technology, Norwegian University of Life Science.

Kelompok Kerja Pengelolaan Gambut Nasional. (2006). Strategi dan Rencana Tindak Nasional Pengelolaan Lahan Gambut Berkelanjutan. Departemen Dalam Negeri, Jakarta.

Miftah, dkk. Komunikasi Pembangunan Partisipatoris dalam Mitigasi Kebakaran Hutan dan Lahan di Provinsi Riau. CCCMS-UII Jogjakarta.

Purwanto, dkk. (2019). Utilization Of Geographic Information System (GIS) For The Prevention Of Land And Forest Fires As Mitigation Efforts For Peatland Disasters. ICKLIK- 126 -177-2-SM. 
Walhi.(2017). Kebakaran Hutan dan Lahan, Menolak Lupa terhadap Kejahatan Korporasi. (http://www.walhi.or.id/2017/07/27/kebakaran-hutan-dan-lahan-menolaklupa-terhadap-kejahatan-korporasi.html diakses pada 20 September 2018)

W.B. Werther, J., \& Chandler, D. (2011). Strategic Corporate Social Responsibility: Stakeholders in a Global Environment. California: Sage Publications. 